\title{
The Impact of Foreign Direct Investment on Economic Growth and Employment in South Africa: A Time Series Analysis
}

\author{
Masipa Tshepo \\ Department of Economics and Management Science, University of Limpopo (Turfloop Campus) \\ Private Bag X1106, Sovenga, 0727. South Africa \\ Email:masipatshepo@gmail.com
}

\section{Doi:10.5901/mjss.2014.v5n25p18}

\section{Abstract}

The aim of this paper was an attempt to estimate the impact of foreign direct investment on economic growth and employment in South Africa for a period of 24 years, thus from 1990 to 2013. The study employed in its analysis, the unit root test to test for stationarity of the time series, the Johansen Cointegration test to test for the existence of long-run relationship among the variables and finally, Granger causality test to establish the causal relationship between the variables. Employment and GDP were found to be stationary at first order difference, while FDI was found to be stationary at level form. The cointegration test confirmed the existence of a long-run relationship between the variables. The Granger Causality test results confirmed the direction of causality which runs from FDI to GDP and from FDI to employment. From the results, there is strong evidence that from 1990 to 2013 there was a positive long-run relationship between FDI, GDP and employment in South Africa. Adding to these tests, various diagnostic tests also confirmed that the research results are reliable. In addition, the paper also identified factors that might affect the flow of foreign investors into South Africa. These factors include; return on investment, human capital, cost of labour, labour disputes and corruption. The government should emphasise more on these factors to make South Africa conducive for foreign investment. My empirical results thus suggest that FDI should be considered as a mechanism to boost long-term economic growth and employment in South Africa.

Keywords: Foreign direct investment, economic growth and employment

\section{Introduction}

For the past two decades, unemployment in South Africa has been one of the biggest problems facing the country. The official rate of unemployment has increased from 17\% in 1994 to over 25\% in 2013 (StatsSA, 2013c). In the first quarter of 2013 , unemployment was reported at $25.2 \%$ and GDP growth at $3.8 \%$ which is less than the desired $5 \%$ annual growth, (StatsSA, 2013c). At a time when the country is struggling with such problems, a plan or a policy for a sustained growth and job creation would be warmly welcomed. With this regard, foreign direct investment (FDI) has been considered as an important source for sustained growth, increasing exports and creating jobs in developing countries.

As noted by the World Bank (2002), several studies concluded that FDI promote economic development of the host country by promoting productivity growth, exports, transfer of technology and creating employment opportunities for economically active citizens in the host country. Considering all the benefits of attracting foreign investors, South Africa just like any other developing country tries as much as possible to create an environment which is conducive for attracting foreign investors. Xolani (2011) also noted that FDI can benefit a country like South Africa, not only by supplementing domestic investment but in terms of job creation, transfer of technology, increasing domestic competition and other positive externalities that come with the attraction of foreign investors.

In addition, Kinda, (2010) stated another reason why FDI is important for South Africa or any other developing economy. In his study, he emphasised that South Africa should acquire more FDI to assist in alleviating some of its socioeconomic problems, such as unemployment and poverty. Caves (1996) mentioned several reasons why should developing countries increase the efforts to attract more FDI. He argued that among other benefits, FDI is expected to increase productivity gains, technology transfers, introduction of new processes, managerial skills and know-how in the domestic market, employee training, international production networks, and access to markets. Furthermore, Rusike (2007) also argued that FDI contributes more jobs to the local economy by directly adding new jobs and indirectly when local spending increases due to purchases of goods and services by the new increase employees. He stated that all this in turn are expected to have positive multiplier effects for an economy.

In his State of Nation Address (SONA), President Jacob Zuma stated that the obvious solution to unemployment, 
poverty and inequality, as identified in the National Development Plan (NDP: vision 2030), is the creation of jobs (SONA, 2013). With the believe that FDI is important to enhance growth and employment in the host country, it is therefore important for the South Africa, policies and incentives to attract more foreign investors to come and invest in south Africa.

It is however important to note that the aim of this paper is not an attempt to criticize the collective efforts taken by the South African government and policy makers to the address issues of sustainable growth and job creation. It is rather an attempt to extend the discussion and debate with regard FDI and its importance to enhance growth and employment in South Africa. The primary goal of this paper is to determine whether there is a long-run relationship between FDI, GDP and employment in South Africa. The paper also seeks to determine the direction of causality between FDI, GDP and employment in South Africa for the period of 1990 to 2013. Therefore, this paper seeks to find out if increased in FDI inflow leads to GDP growth and employment or vice versa. More importantly, the results of this paper will provide a clear view of whether FDI should be consider as a policy for long-term growth and employment creation in South Africa.

However, for as much as FDI is important economic developing in most emerging economies, it is essential to also acknowledge that there is conflicting evidence in the literature regarding the question as to how and to what extent FDI affects economic growth and employment of the host country. The effects FDI on the economy of the host country seem to differ from one country to another and it is for this reason that, Chowdhury and Mavrotas (2005) suggested that it would be worthwhile to have an individual country study which would help in ascertaining the impact of FDI on economic growth and employment. Taking that suggestion into consideration, this study therefore seeks to ascertain the impact of FDI on GDP growth and employment in South Africa for the period 1990 to 2013. This objective will be achieved by employing various econometric tests which will be outlined and discussed clearly in section three. These tests together with their hypothesis will establish whether FDI has or had a positive impact of economic and employment in South Africa for the period under review.

This paper is divided into five sections. Apart from section one which dealt with the introduction and research objectives, section two reviews relevant literature of FDI and its impact on economic growth and employment in various countries. Section three presents the research methodology. Section four presents results of the study. Lastly, section five presents conclusion together with recommendations proposed by the author of this study.

\section{Literature Review}

For the purpose of providing a clear picture of what FDI is, it is therefore important for this section to start by outlining some definitions of FDI, types, motives as well as its determinants to ensure that the meaning of the concept is clearly understood.

\subsection{What is foreign direct investment?}

According to the International Monetary Fund (IMF) (2008), foreign direct investment is defined as an investment involving a long-term relationship and reflecting a lasting interest and control by a resident firm in the economy of the host country. Matjekana (2002) noted that FDIs are broadly classified in terms of the directions of the flows, namely inward and outward. He based this classification on the types of restrictions of these investments. He defined inward FDI as investment in which foreign capital is invested in local resources and outward FDI as investment of local capital invested in foreign countries.

As we have observed in the literature, FDI can also be divided into horizontal and vertical FDI. According to Fedderke and Romm, (2006), horizontal FDI refers to a case in which Multinational Corporations (MNCs) have their headquarters in their home country and have production plants both at home and abroad that produce the same goods. On the other hand, they defined vertical FDI as investment in which MNCs portion different stages of production by having their headquarters in their home country and production plants in different foreign countries. They indicated that vertical FDI is traditionally related to the desire of Multinational Enterprises (MNEs) to carry out unskilled-labour intensive production activities in locations that are relatively abundant with unskilled labour.

Even though it is generally believed that both horizontal and vertical FDI are important for economic growth and job creation, some authors did not find and long term positive effects of these investments on the host country's economy. For instance, Herzer (2008) studied the impact of horizontal and vertical FDI in 28 developing countries and he did not find any evidence of positive effects of FDI on GDP for most countries. In addition, Herzer argued that FDI can only create jobs in the host country if it is labour intensive rather than capital.According to Moolman, Roos, Le Roux and Du Toit (2006), FDI can also be divided according to its motives, namely: resource-seeking, market-seeking and efficiencyseeking FDI. They stated that resource seeking FDI is related to the presence of natural resources in the host country. 
They suggested that resource driven FDI includes the availability of low cost unskilled labour, skilled labour and quality of physical infrastructure as determinants of FDI. They further stated that, given the abundance of natural resources in Africa, a greater amount of FDI would be expected to be in the primary sector. They identified the size of the market (GDP growth) as the main determinant market-seeking investors.

In addition, Asiedu (2006) stated that the main objective of market seeking FDI is to serve domestic markets, which means that goods are produced in the host country and sold in the local market. As a result this type of FDI is driven by domestic demand such as large markets and high income in the host country. He emphasized that market size, wage levels and growth becomes the essential characteristics for countries which host market-seeking FDI. According to Kransdorff (2010), efficiency-seeking FDI focuses primarily on the export market as opposed to the host market and so the determinants of this type of investment will be the lowest cost and lowest risk environment, including factors such as infrastructure, wage costs and taxes. He argued that efficiency-seeking FDI tends to be footloose with relatively narrow margins, thus making it less reliable and less-conducive to a country's long-term development as it is liable to leave as soon as another country offers a cheaper production environment.

Branstetter (2006) argued that the tool that is used for inward FDI and the type of FDI received by a country will have different impact on job creation for the domestic economy. He emphasized that the impact of Greenfield investment on job creation is direct as new firms require labour to operate. Kim (2009) stated that the direct effects of inward FDI on employment refers to the contribution of FDI to employment creation. He stated that the impact of attracting FDI on employment will be higher only if the FDI activities are labour intensive.

Having outlined a clear view of what FDI is, it is therefore important to also highlight some possible factors which can affect the flow of FDI into the host country. These factors determine the areas which foreign investments are likely to flow in.

\subsubsection{Return on investment}

Because of the profit motive, return on investment, has been widely considered as one of the main determinant of FDI inflows in many studies of FDI. According to Carim, (1994) two fundamental conditions for foreign investment are profitability and investor confidence. He argued that both are reliant on stable political and macroeconomic policies that are consistent and transparent and help to induce economic growth and encourage investment. He stated that greater political stability in a country will result in a higher probability of revenues appropriated by the multinational from sales made in that country. Onyeiwu (2003) noted that the profitability of investment is of primary interest to foreign investors. He argued that the decision to invest in a host economy, therefore depends on the risk and return on investment in the economy. He further emphasized that portfolio theory contends that capital tends to flow to economies with low risks and high rates of return on investment. He also noted that in very risky economies, the risk-adjusted rate of return on investment must be reasonably high in order to attract FDI.

\subsubsection{Cost of labour}

Foreign investors are alleged to take advantage of low labour costs by investing in developing countries where such costs are low. To assess the cost of labour, Dunning (2008) argued that real wage rates are used as main determinant to determine the cost of labour in the host country. He highlighted that lower real wages in a host country are expected to attract FDI. He also noted that the main focus is not solely on cheap labour but also to take into consideration productivity, flexibility and adaptability of the labour force in the host country, which effectively reduces costs. In addition, Fazeka (2005) studied the effect of wage rates on FDI in the transition countries of Eastern Europe. His results found a strong evidence of a negative relationship between FDI inflows and average wage rates. His findings were also supported by a number of studies including that of Addison and Dunning (2008) and Asiedu (2006).

\subsubsection{Availability of human capital}

Human capital is also said to be one of the main factors in determining the location of foreign investors into the host country. Rusike (2007) conducted an econometric analysis to test for the effects of school enrolment on FDI inflows. He found that the proxy for local skills and human capital was strongly and significantly positively related to FDI inflows to those developing countries tested in the sample. Gelb (2002) also found a strong positive correlation between secondary school enrolment and FDI. He found that not only is local skills a strong determinant of FDI, but its importance is crucial for the host country to reap the benefits from foreign investment. He argued that the Multinational Corporations (MNCs) 
may bring advanced capital into a country, but if the local population are unable to understand or use them, then it will have no benefit on the economy of the host country as a whole.

However, Bende-Nabende (2002) studied the determinants in Sub-Saharan countries, he argued that no definite conclusions can be drawn about mean years of education and real wages rates as the main determinants of foreign investors, because some countries in the Sub-Saharan Africa (SSA) sample did not have sufficient time-series data for both variables. They also found that the availability of relatively skilled labour do not appear to have been a major factor in the location decision of MNCS.

\subsubsection{Availability of natural resources}

Another major determinant of FDI in the host country is the endowments of natural resources, especially for resourceseeking FDI. A study by Asiedu (2006) found natural resource endowments as a major determinant of FDI. He found that developing countries with rich endowments of natural resources tend to attract greater inflows of resource-seeking FDI. $\mathrm{He}$ also found a strong correlation between FDI inflows and natural resources (share of minerals and oil) and market size for a sample of African states over time. He concluded that developing countries that attract greater FDI are those that are endowed with natural resources.

In addition, Xolani (2011) found that South Africa is rich with natural resources, relatively low cost of doing business, a relatively stable political regime and good infrastructure as compared to the rest of African economies which will result in high return on investment. This gives South Africa an advantage if it wishes to attract resource-seeking FDI. However, Dunning (2008) noted that FDI is not always good for the host country, particularly resource-seeking FDI, because it could imply low value adding activity and low capital expenditure on plant and equipment with the exception of extractive industries. They emphasized that MNEs should thus be encouraged to invest in higher value adding activities which could come in the form of market seeking and other asset exploiting activities.

\subsubsection{Political instability and Corruption}

Political instability has been noted by a number of researchers to have a negative and statistically significant impact on both foreign and domestic investment in developing countries. Xolani (2011) argued that a political environment that is not stable has the capacity of scaring away investors. For example, a number of investors highlighted that the South African political environment is constantly stable except during strikes. Xolani emphasised that political instabilities are major constraints to foreign investment into the host country and that high incidence of wars and civil unrest may also increase uncertainty and therefore risk for investors.

As for corruption, Asiedu (2002) found that corruption has a significantly adverse effect on FDI inflows. He also found that corruption is correlated to other explanatory variables such as political and macroeconomic stability and thus corruption has an indirect effect as well as the direct effect on FDI flows. He argued that corruption and lack of transparent governance are key restrictions to foreign investment and that a country with high level of corruption cannot attract many investors effectively.

It is however unfortunate that the image of the African countries as a destination of FDI inflow has been seen as 'unfavourable' by many foreign investors because investors see the continent as a home for wars, civil unrest, poverty, diseases and a generally unfriendly investment destination. In addition, Asiedu (2002) stated that being an 'African country' is indeed a significantly negative determinant of FDI, because of investor's perceptions of Africa as inherently risky. Nevertheless, due to fact that Africa is blessed with natural resources, foreign investors are keen to invest in the continent.

\subsubsection{Market size}

Market size and its growth is also regard as another important determinant of foreign investment inflows into the host country. According to Asiedu (2006) a number of studies carried out in this area have established a correlation between FDI and the size of the market (proxied by the size of GDP). He argued that many of those studies have found GDP growth rate to be a significant explanatory variable of foreign investment decisions. Moolman, et al. (2006) ran an analysis of South Africa's FDI inflows for the period 1970 to 2003. They found that the most significant determinants of FDI for South Africa included openness (market size), which had both short and long term positive relationship on FDI.According to Lim (2001) market-seeking FDI requires a large market for efficient utilization of resources. He stated that the large market reduces the cost of production because of lower fixed costs and economies of scale. He stated that 
as the market size of a country grows, it is expected that inward FDI will also increase as more goods and services can be produced. An important question in most studies of FDI relates to its impact on economic growth and job creation in the host country. The section below reviews the relationship between FDI, economic growth and employment.

\subsection{The impact of foreign direct investment on economic growth and employment}

Despite a huge number of studies on FDI and its impact on the economic growth of the host countries, the empirical findings still provide an unclear picture of this relationship. There are however, some general conclusions regarding this relationship. In most literature, FDI is generally accepted as a vehicle for sustainable growth via its positive spill over effects, such as job creation, transfer of skills and technology, increasing competition and enhancing human capital in the host country.

Theoretically, Xolani (2011) argued that inward FDI has a positive impact on economic growth of a host country through increased capital accumulation, access to superior technology, greater efficiency, increased competitiveness and exports. He noted that the extent to which inward FDI positively impacts on growth depends on the quality of economic environment. In addition, Li \& Liu, (2005) used a dataset covering 84 countries in both developed and developing countries over the period of 1970 to 1999. They found a positive and statistical significant effect of FDI on economic growth and employment in most developing countries. They reported that this relationship has become more endogenous over time. According to the study done by Agrawal (2000) on economic impact of foreign direct investment in South Asia by employing cross-section analysis of panel data from five South Asian countries; India, Pakistan, Bangladesh, Sri Lanka and Nepal. He found evidence that there is a linkage effect between foreign and domestic investment. He argued that the impact of FDI on GDP growth is negative prior to 1980s and strongly positive in early nineties. In addition, Hansen and Rand (2004) in their study used a sample of 31 developing countries and estimators for heterogeneous panel data, found a bi-directional causality between FDI/GDP and the level of GDP. They interpreted this result as evidence in favour of hypothesis that FDI has an impact on GDP via knowledge transfers and adoption of new technology. Their results showed that a one percentage point increase in FDI leads to a 2.25\% increase in GDP growth.

A study by Borensztein, De Gregorio and Lee (1998) tested the effect of FDI on economic growth in 69 developing countries. This study found a positive correlation between growth rate and FDI and showed that the contribution of FDI in economic growth depends on the capacity of assimilation of technology by the host countries. They noted that there is complementarity between human capital and FDI is considered as being necessary. In addition, Chowdhury and Mavrotas (2005) produced empirical evidence on the relationship between FDI and economic growth obtained from single-equation and simultaneous equation estimates for 140 countries using macro-economic variables. Their results indicate a positive and statistically significant estimate of coefficient of FDI and economic growth.

However, stated that though it may be the case that foreign investment leads to employment creation in the host country there is also a concern that while FDI does succeed in creating jobs, income inequality in the country may become more skewed. He argued that this would be the case where employment and training is given to more educated and typically wealthy elites and that capital-intensive FDI may fail to create many jobs. He noted that foreign firms may adopt capital-intensive modes of production using technologies developed abroad thus not needing to employ local people.

In view of the above literature, it is clear that the impact of FDI on economic growth and employment seems to be country based and it can either be positive, negative or inconclusive depending on the economic conditions of each country. This is also due to different methodologies and samples used by different researchers. The next section provides the methodology and discussion of research results.

\section{Research Methodology and Discussion of Results}

This study is largely quantitative and builds on existing body of knowledge by determining the impact of FDI on economic growth, measured by GDP growth and employment in South Africa for the period 1990 to 2013. In this study, the researcher used three econometric tests to test for the relationship between FDI, GDP and employment in South Africa. These tests are; the unit root test to test if the variables used in the model are stationary or not; cointegration test to test whether there is a long-run relationship between FDI, GDP growth and employment, and granger-causality test to determine the direction of causality between these variables. In addition, various diagnostic tests were also tested to ensure that the research results are reliable. 


\subsection{Unit-root test: Test for stationarity}

According to Gujarati and Porter (2009), statistical tests such as t-stats, F-stats and $\mathrm{R}^{2}$ are not applicable in a nonstationary time series due to non-standard distributions. It is therefore recommended that a stationarity (unit root) test is carried out to test for the order of integration. The study performed the stationarity tests using the Augmented DickeyFuller (ADF). In testing for the existence of a stationarity, the study followed the following three sequences;

With constant and trend ( $\left.t_{t}\right) \quad \Delta Y_{t}=\partial Y_{t-1+\mu_{t}}$

With constant only ( $\left.t_{u}\right) \quad \Delta Y_{t}=\alpha+\partial Y_{t}-1+\mu_{t}$

Without constant and trend $(t) \Delta Y_{t}=\alpha+\beta_{t}+\partial Y_{t}-1+\mu_{t}$

The unit root test was applied to test the stationary of the time series data at a level form and first differenced using ADF test. If the test is significant at a given level of significance (5\%), it means the series is stationary and does not have unit root, so the null hypothesis will be rejected and the alternative will be accepted.

\subsection{Cointegration test}

Another way to overcome the problem of non-stationarity is through the concept of cointegration. Cointegration is based on the premise that two or more non-stationary variables which have a long-run relationship will give stationary results for a linear combination of variables when regressed on each other (Gujarati and Porter, 2009). If the null hypothesis is rejected, we therefore accept the alternative hypothesis and conclude that cointegration exists.

\subsection{Granger causality test}

According to Gujarati and Porter, (2009), Granger causality test is a statistical hypothesis test for determining whether one series is useful in forecasting another. For instance, a time series $\mathrm{X}$ is said to Granger-cause $\mathrm{Y}$. Using $\mathrm{t}$-tests and $\mathrm{F}$ tests, the values of $X$ can provide information about the future values of $Y$. The hypotheses of this paper are formulated in their null form and are expressed as follows:

$\mathrm{HO}_{1}$ : $\mathrm{FDI}$ does not granger-cause economic growth in South Africa

$\mathrm{HO}_{2}$ : FDI does not granger-cause employment in South Africa

Testing for causality upholds the standard procedure outlined by Gujarati and Porter (2009). The hypotheses will first be tested and then compared with the F statistics values. If the F-statistic values are greater than the probability values, we then conclude by rejecting the null hypotheses and accept the alternative hypotheses.

\section{Research Results}

This section presents the results of all tests employed in the study. These tests include; Unit root test; Cointegration and Granger causality test. In addition, results from various diagnostic tests are also presented. All these tests were computed using statistical package called E views.

\subsection{Results of unit root test (testing for stationarity)}

Table 1 below summarises the results of unit root test. From the results, employment (EMP) is non-stationary at level form but stationary at the first order difference. Since the critical value is greater than t-statistics in the first order difference (D_EMP), this led to the rejection of null hypothesis at first order difference, implying that the series are integrated at first order difference. The results also indicate that FDI is stationary at the level form, thus implies no need to difference them at first order. Lastly, GDP showed evidence of non-stationarity at level form but when differenced at first order (D_GDP), it was stationary. The ADF statistics used in the test is a negative number. The more negative the ADF values are, the stronger the rejection of the hypotheses. The table below presents the result for the statitionary test employed both at level form and first order difference. 
Table 1: Summary of unit root test

\begin{tabular}{|c|c|c|c|c|}
\hline Series & Model & lags & ADF test & $\phi 3$ \$1 \\
\hline EMP & $\begin{array}{c}\text { Trend and intercept } \\
\text { Intercept } \\
\text { None }\end{array}$ & $\begin{array}{l}2 \\
2 \\
2\end{array}$ & $\begin{array}{l}-1,446777 \\
-0.396603 \\
-0.655694 \\
\end{array}$ & $\begin{array}{l}2,905103 \\
0.157294\end{array}$ \\
\hline D_EMP & $\begin{array}{c}\text { Trend and intercept } \\
\text { Intercept } \\
\text { None }\end{array}$ & $\begin{array}{l}2 \\
2 \\
2 \\
\end{array}$ & $\begin{array}{l}-5.668775^{\star \star} \\
-3.815411^{\star \star} \\
-3.829592^{\star \star} \\
\end{array}$ & $\begin{array}{l}14.54838^{* *} \\
14.40422^{\star *}\end{array}$ \\
\hline FDI & $\begin{array}{c}\text { Trend and intercept } \\
\text { Intercept } \\
\text { None }\end{array}$ & $\begin{array}{l}1 \\
1 \\
1\end{array}$ & $\begin{array}{l}-5.196047^{\star \star} \\
-4.261349^{\star \star} \\
-4.399817^{\star \star}\end{array}$ & $\begin{array}{l}13.54858^{* *} \\
18.15909^{* *}\end{array}$ \\
\hline GDP & $\begin{array}{l}\text { Trend and intercept } \\
\text { Intercept } \\
\text { None }\end{array}$ & $\begin{array}{l}1 \\
1 \\
1\end{array}$ & $\begin{array}{c}-3.285188^{\star} \\
-3.368741^{\star \star} \\
-1,319874\end{array}$ & $\begin{array}{l}5.831817^{*} \\
11.34842^{\star *}\end{array}$ \\
\hline D_GDP & $\begin{array}{c}\text { Trend and intercept } \\
\text { Intercept } \\
\text { None }\end{array}$ & $\begin{array}{l}1 \\
2 \\
1\end{array}$ & $\begin{array}{l}-5.866046^{\star \star} \\
-5.802088^{\star \star} \\
-5.928352^{\star \star}\end{array}$ & $\begin{array}{l}17.21383^{* *} \\
33.66422^{\star *}\end{array}$ \\
\hline
\end{tabular}

Note: $\mathrm{H}_{0}$ : series has unit root; $\mathrm{H}_{1}$ : series is stationary: $\left.{ }^{*}{ }^{* *}\right)$ indicate the rejection of the null hypothesis at $5 \%(1 \%)$ level of significance

The theory of cointegration is considered as one of the most important new concepts in the field of econometrics and time series analysis. The cointegration test clearly identifies the real long-run relationship between the variables in the model (Gujarati and Porter, 2009). Therefore, having established that the time series are integrated both at level form and first order difference, the next step in testing the relationship between FDI, GDP and employment is to test for the cointegration using Johansen cointegration test.

\subsection{Table 2: Results of cointegration test}

Null hypothesis: No cointegreaion between variables

\begin{tabular}{|c|c|c|c|c|}
\hline Hypothesized No. of CE(s) & Eigenvalue & Trace statistic & Critical Value at 5\% & Prob. \\
\hline None * $^{*}$ & 0.598186 & 46.65330 & 29.79707 & 0.0003 \\
\hline At most 1 & 0.552320 & 27.50619 & 15.49471 & 0.0005 \\
\hline At most 2 * & 0.397183 & 10.62897 & 3.841466 & 0.0011 \\
\hline
\end{tabular}

Note: Reject Ho if PV is less than 5\%: Do not reject Ho if PV is greater than 5\%:***) indicate the rejection of the null hypothesis at $5 \%(1 \%)$ level of significance

The test is performed in order to determine the existence of co-integration relationship between FDI, GDP and employment in South Africa. Comparing the critical values and the probability values, we therefore conclude by rejecting the null hypothesis $5 \%$ level of significance. It is therefore concluded that there is co-integration between the variables in the model, and thus, a long run relationship does exists between FDI, GDP and employment in South Africa. This longrun relationship is also confirmed by the trace statistics which are all greater than the critical values at $5 \%$ level of significance.

The results of this study are similar to that of Bengoa and Sanchez-Robes (2003) who found that foreign direct investment has a positive and significant impact on economic growth and employment in developing countries using cross-section data and the Cointegration test. They emphasized that the magnitude of this impact is dependent to the conditions and economic characteristics of the host country. In addition, Zhang (1999b) applied cointegration test and error-correction model to investigate the long-run relationship and the short-run dynamics between FDI and economic growth in China. His findings support the existence of a long-run relationship between FDI and economic growth in China. With an effort to determine the causal relationship between FDI, GDP and employment in South Africa, the table below presents of pairwise Granger causality test. 


\subsection{Table 3: Result of Granger-causality test}

Lags: 2

\begin{tabular}{|l|c|c|c|}
\hline Null Hypothesis: & Obs & F-Statistic & Prob. \\
\hline H01: LNFDI does not Granger Cause LNGDP & 22 & 0.8489 & 0.4452 \\
\hline H02: LNFDI does not Granger Cause LNEMP & 22 & 7.5116 & 0.0046 \\
\hline
\end{tabular}

Note: Reject Ho if PV is less than 5\%: Do not reject Ho if PV is greater than $5 \%$ level of significance:*(**) indicate the rejection of the null hypothesis at $5 \%(1 \%)$ level of significance

From the results above, the F-statistic and the probability values indicate whether the null hypothesis should be accepted or rejected. In this case, we reject the null hypothesis if $\mathrm{F}$ statistic is greater than the probability value. For $\mathrm{HO}_{1}$, the $\mathrm{F}$ statistic of 0.8489 is greater than the probability value of 0.4452 which indicates causal relationship that runs from LNFDI to LNGDP. For $\mathrm{HO}_{2}$, the $\mathrm{F}$ statistic of 7.5116 is greater than the probability value of 0.0046 which also indicates that there is causality which runs from LNFDI to LNEMP in South Africa for the period under review, thus from 1990 to 2013.

Similarly, Zhang (1999a) who in his study investigated the causation of FDI and economic growth in 10 East Asian economies also found that FDI appears to enhance economic growth in the long run for China, Hong Kong, Indonesia, Japan and Taiwan and in the short run for Singapore. In addition, Nair-Reichet and Weinhold (2001) applied a fixed and random estimation to examine the relationship between FDI and economic growth in developing countries and find that there is a causal link between FDI and growth. However, Kholdy (1995) noted that one important problem is the possibility of endogeneity of the variables. To deal with this issue, he indicated that the bilateral causality testing can be employed. Using data from 10 East Asian economies, he carried out Granger causality test but did not find any causation between FDI and GDP in the long run. Similarly, using data on 80 countries for the period 1971 to 1995, Choe (2003) detected a two-way causation between FDI and economic growth and he also found that the effects are more apparent from growth to FDI.

Although the null hypotheses of this study are rejected, this might not reflect the reality. It is important to note that other variables can be used and possibly gives different results, and that the causality relationship between FDI and economic growth differs from country to country. What makes this study interesting is that it included employment as a variable depending on FDI and economic growth. With crisis of unemployment in South Africa, further researches should be conducted concerning the relationship between FDI and employment in South Africa. The table below present the results of all diagnostic test employed.

\subsection{Table 4: Results of diagnostic tests}

\begin{tabular}{|l|l|c|l|l|}
\hline Test & Ho & T-stat & P-value & Conclusion \\
\hline Jarque-Bera & $\begin{array}{l}\text { Residuals are normally } \\
\text { distributed }\end{array}$ & 1.29921 & 0.52251 & $\begin{array}{l}\text { Do not reject Ho since PV is greater than 5\%. Hence, residuals } \\
\text { are normally distributed. }\end{array}$ \\
\hline $\begin{array}{l}\text { Breusch- } \\
\text { Godfrey }\end{array}$ & No Serial correlation & 17.6950 & 0.43181 & $\begin{array}{l}\text { Do not reject Ho since PV is greater 5\%. Hence, there is no } \\
\text { serial correlation in the model. }\end{array}$ \\
\hline White (CT) & No Heteroskedasticity & 5.88003 & 0.32315 & $\begin{array}{l}\text { Do not reject Ho since PV is greater than 5\%. Hence, there is } \\
\text { no heteroskedasticity in the model }\end{array}$ \\
\hline
\end{tabular}

Table 4 presents the results from other diagnostic tests which were carried out in this study in order to determine the quality of the models used. These results are tested based on the level of significance of $5 \%$. According to Jargue-Bera test, the residuals of the regression are normally distributed in the model because the $p$-value of 0.52 .2251 is greater than $5 \%$ level of significance. Breusch Godfrey test denotes that there is no serial correlation in the model, because the pvalue of 0.43181 is greater than $5 \%$ level of significance. White (CT) test indicates that there is no problem of heteroskedasticity in the model because 0.32315 is greater than $5 \%$ level of significance. Looking at the results of the diagnostic tests, one would say that the results of this study are more reliable

\section{Conclusion}

This paper was an attempt to empirically establish the relationship between foreign direct investment, economic growth and employment in South Africa by employing the unit root, cointegration and granger causality test using a time series annual data within the period of 1990 to 2013. Various diagnostic tests were also employed to test the reliability of the results. The unit root test showed that employment and GDP were non-stationary at level form but stationary at first order 
difference. FDI was found stationary at level form, thus implies that there is no need to difference it.

From the findings of this study, there is evidence that there is a long-run relationship between foreign direct investment, economic growth, measured by GDP growth and employment in South Africa for the period under review. The Granger-causality test also revealed that both GDP growth and employment were granger-caused by FDI. This shows that South Africa's capacity to progress on economic growth will depend on the country's performance in attracting foreign direct investment. This study supports the hypothesis that FDI has a positive impact of FDI on GDP growth and employment in South Africa from 1990 to 2013. This calls for policies and incentives aimed at of foreign investors to enhance sustainable growth and employment in South Africa and other developing countries. In addition to these tests, diagnostic tests were also employed and their null hypotheses were not rejected. Thus, implies that residual are normally distributed, no serial correlation and no heteroscedasticity.

On the basis of the results, few suggestions can be made: Firstly, the attraction FDI in South Africa should not be seen as an end in itself, but also as a means of supporting other development initiatives such as reducing inequalities and poverty. Secondly, the findings of this paper should also serve as a guideline to policy makers and economists in identifying areas which should be emphasized on when attracting foreign direct investors into South Africa or any other developing country. Thirdly, due to the perceived importance of FDI on economic growth and job creation, FDI should therefore be studied and extensive researches should be done in order to have a clear understanding of what its contribution to growth and employment are. Finally, trade unions should emphasize more on stabilizing labour disputes especially in mining sector in South Africa. More important, the government should also emphasise more on fighting corruption.

\section{References}

Agrawal P. (2000), "Economic Impact of Foreign Direct Investment in South Asia". Indira Gandhi Institute of Development Research, Bombay, India.

Asiedu, E. (2002). On the Determinants of Foreign Direct Investment in Developing Countries. Is Africa Different? World Development. 30:107-119.

Asiedu, E. (2006). Foreign Direct Investment in Africa: The role of natural resources, market size, government policy, institutions and political instability. University of Kansas United Nations University: 63-75.

Bende-Nabende, A. (2002). Foreign Direct Investment Determinants in Sub-Saharan Africa: A Co-Integration Analysis, Economics Bulletin, 6 (4), pp. 1-19.

Bengoa, M. and Sanchez-Robles B. (2003), "Foreign Direct Investment, economic freedom and growth: New evidence from Latin America". European Journal of Political Economy, 19(3): 529-45.

Branstetter, L. (2006). Is foreign direct investment a channel of knowledge spillovers? Evidence from Japan's FDI in the United States. Journal of International Economics, 68 (2), 325-344.doi: DOI.

Borensztein, E.; Gregorio, J-De. and Lee, J.W. (1998), "How does Foreign Direct Investment Affect Economic Growth?". Journal of International Economics. Vol. 45. pp: $115-135$.

Carim, X. (1994). Some Trends in Foreign Direct Investment: Implications for South Africa. South African Perspectives, A Working Paper Series. University of the Western Cape: 1-23.

Caves, R.E. (1996), Multinational Enterprise and Economic Analysis. 2nd ed. Cambridge: Cambridge University Press.

Chakraborty, C. and Basu, P. (2002). Foreign direct investment and growth in India: A cointegration approach. Applied economics, 34(9), 1061- 112.

Choe, J.I. (2003). Do foreign direct investment and gross domestic investment promote economic growth? Review of Development Economics, 7(1), 44-57.

Chowdhury, A. and Mavrotas, G. (2005), "FDI and Growth: A Causal Relationship", UNUWIDER Research Paper No. 2005/25, UNUWIDER.

Dunning, J. (2008). Multinational Enterprises and the Global Economy, second edition, Edward Elgar, Cheltenham, UK, Northampton, MA, USA.

Fedderke, J. W, and Romm, A. T. 2006. Growth impact and determinants of foreign direct investment into South Africa, 1956-2003. Economic Modelling, 23 (5).

Frenstra. R, and Markusen, L. (1994) "Accounting for Growth with New Inputs". International Economic Review. Pp 429-447.

Fazekas, K. (2005). Effects of FDI inflows on regional labour market differences in Hungary. Economie international, 102: 83-105.

Gelb, S. (2002). Foreign Companies in South Africa: Entry, Performance and Impact. The Edge Institute, South Africa: 1-23.

Gujarati, DN. and Porter, D.C. (2009). Basic Econometrics (International Edition).5th Edition. McGraw-Hill//rwin.

Hansen, H. and Rand, J. (2006). On the causal links between FDI and growth in developing countries. World Economy, 29, 21-4.

Herzer, D. (2008). In search of FDI-led growth in developing countries: The way forward. Economic Modelling.

IMF, (2008). International Monetary Fund Country Report 06/328. South Africa.

Johnson, A. (2006). "The Effects of FDI Inflows on Host Country Economic Growth", CESIS Electronic Working Paper Series, Electronic Working Paper Series, Paper No.58. 
Kholdy, S., (1995). 'Causality between foreign investment and spillover efficiency', Applied. Economics, 27: 74-749.

Kim, Y. (2009). Cross-border M \& A vs. Greenfield FDI: Economic Integration and its welfare impact. Journal of Policy Modelling. 63.

Kinda, T. (2010). Investment climate and FDI in developing countries: Film-level evidence. World Development.

Kransdorff, M. (2010). Tax Incentives and Foreign Direct Investment in South Africa. Consilience: The Journal of Sustainable Development, 3(1): 68-84.

Lim, D. (2001). Fiscal Incentives and Direct Foreign Investment in Less Developed Countries. Journal of Development Studies, 19(2): 207-212.

Li, X and Liu, X. (2005). Foreign Direct Investment and Economic Growth: An increasingly Endogenous Relationship. World Development, 33(3): 393-407.

Matjekana K S M, 2002. Foreign Direct Investment Flows in the SADC Region in a Globalising Economic Environment. Rand Afrikaans University, Johannesburg.

Moolman, C; Roos, E; Le Roux, J \& Du Toit, C. 2006. Foreign Direct Investment: South Africa's Elixir of life? Department of Economics Working Paper Series. Pretoria.

Nair-Reichert, U., and Weinhold, D. (2001). Causality tests for cross-country panels: A new look at FDI and economic growth in developing countries. 64 .

Onyeiwu, S, (2003). "Analysis of FDI Flows to Developing Countries: Is the MENA Region Different?" Paper presented at the ERF 10th Annual Conference, December.

Rama, M. (2003). "Globalization and workers in developing countries", World Bank Policy Research Working Paper, No. 2958 (Washington, D.C: World Bank).

Rusike T.G. (2007). Trends and Determinants of inward Foreign Direct Investment to South Africa. Rhodes University.

State of the Nation Address by His Excellency JG Zuma, at the Joint Sitting of Parliament, Cape Town. [15 June, 2014].

Statistics South Africa. (2013). Annualised GDP time series. Available [Online] at www.statssa.co.za. Accessed 12/08/2014.

UNCTAD, (2006). "FDI from Developing and Transition Economies: Implications for Development", World Investment Report. 65.

World Bank (2002). Transnational Corporation and Export Competitiveness. UNTACD: New Yorkand Geneva.

Xolani, H. (2011). The employment spillover of Foreign Direct investment and host country. Gordon Institute of Business Science. University of Pretoria.

Zhang, K.H. (1999a). Foreign direct investment and economic: Evidence from ten East Asian economies. Economia Internazionale, 51(4), 517-535.

Zhang, K. H. (1999b). How does FDI interact with economic growth in a large developing country? The case of China. Economic System, 21(4), 291- 304. 